\title{
Znaczenie państw Maghrebu w polityce Królestwa Hiszpanii przed akcesją do Unii Europejskiej
}

\section{Streszczenie}

Analizując znaczenie Maghrebu w polityce zagranicznej Hiszpanii, należy zwrócić uwagę na jego geostrategiczne położenie między Europą a Afryką. Z tego wynika priorytetowe traktowanie państw południowej części basenu Morza Śródziemnego. Istotne są również ich doświadczenia historyczne oraz pluralizm socjokulturowy (zderzenie cywilizacji chrześcijańskiej i muzułmańskiej). Na uwagę zasługują także wzajemne stosunki gospodarcze. Relacje Hiszpanii z Maghrebem są często postrzegane wyłącznie przez pryzmat stosunków z Marokiem. Opisać je można jako tzw. relación obcesiva. Przez dziesięciolecia w relacjach dwustronnych przede wszystkim skupiano się na problemach takich jak: imigracja, posiadłości hiszpańskie w Afryce Północnej, a także kwestia Sahary Zachodniej. Celem głównym dla Hiszpanii była stabilizacja nie tylko Maroka, ale całego Maghrebu. Strategiczne znaczenie regionu wynikało z jego bliskości geograficznej, potencjału ekonomiczno-handlowego oraz wpływów kulturowych.

Słowa kluczowe: Hiszpania, polityka zagraniczna, stowarzyszenie, umowa, Unia Europejska Kody klasyfikacji JEL: F50, F54, F55

\footnotetext{
1 Uniwersytet Jagielloński w Krakowie, Wydział Filozoficzny, Instytut Religioznawstwa, Polska, e-mail: justyna.salamon@doctoral.uj.edu.pl, https://orcid.org/0000-0001-7105-2420
} 


\title{
The importance of the Maghreb countries in the policy of the Kingdom of Spain before its accession to the European Union
}

\begin{abstract}
When analyzing the importance of Maghreb in Spain's foreign policy, attention should be paid to its geostrategic location, between Europe and Africa. This gives priority to southern Mediterranean countries. The historical experiences and socio-cultural pluralism (the clash of Christian and Muslim civilizations) are also important. The mutual economic relations deserve attention. Spain's relations with the Maghreb are often seen only through the prism of relations with Morocco. They can be described as so-called relación obcesiva. For decades, bilateral relations focused primarily on issues such as immigration, Spanish possessions in North Africa, and the issue of Western Sahara. The main goal for Spain was to stabilize not only Morocco but all of the Maghreb. The strategic importance of the region was due to its geographical proximity, economic and trade potential as well as cultural influences.
\end{abstract}

Keywords: agreement, association, European Union, foreign policy, Spain

JEL Classification Codes: F50, F54, F55

Przedmiotem opracowania jest analiza polityki zagranicznej Hiszpanii w okresie frankistowskim i w czasie transformacji ustrojowej. W konsekwencji w strukturze artykułu wyróżniono dwie zasadnicze części, obejmujące lata 1939-1975 oraz 1975-1986. W trakcie analizy instytucjonalno-prawnej dokumentów odnoszących się do polityki zagranicznej wskazano na hiszpańskie inicjatywy dotyczące regionu Maghrebu oraz umowy regulujące relacje bilateralne z państwami z sąsiedztwa oraz ze sprzymierzeńcami (Pereira Castanares, 2004: 11). Dla całościowego ujęcia badanej problematyki uzupełniono artykuł o analizę sytuacji wewnętrznej Hiszpanii w kontekście wpływu zmian rządu na politykę zagraniczną, zwłaszcza w okresie demokratyzacji, kiedy wybory wygrywali naprzemiennie socjaliści oraz konserwatyści. Niezależnie od opcji politycznej sprawującej władzę, spośród państw Maghrebu, Maroko było priorytetem dla hiszpańskiej polityki zagranicznej na równi z dążeniem do przyjęcia Hiszpanii do Wspólnot Europejskich. Wynika to m.in. z prezentowanych w dalszej części artykułu umów bilateralnych. Głównym celem opracowania było zaprezentowanie przekrojowo-historycznego obrazu problematyki relacji Hiszpanii z państwami Maghrebu, gdyż nadal nie jest ona zbyt popularna na gruncie polskiej nauki.

Politykę publiczną definiuje się jako dyscyplinę związaną z projektowaniem i wdrażaniem przedsięwzięć. Obejmuje ona również planowanie i realizację interwencji 
na rzecz szeroko pojętego rozwoju ekonomicznego państwa czy rozwiązywanie problemów związanych z bezrobociem itp. Od czasów Harolda D. Lasswella cechą niezmienną polityki publicznej jest jednak wielodyscyplinarność, choć w różnych krajach zauważamy odmienne podejścia badawcze. Jedno z nich obejmuje teorie zarządzania publicznego i ekonomię, drugie koncepcje socjologiczno-politologiczne. Niniejszy artykuł odnosi się w części do kategorii takich jak państwo oraz instrumenty prawne i ekonomiczne (Szatur-Jaworska, 2018: 8-10). Ważną wartością uwzględnianą w analizie jest przestrzeganie reguł państwa demokratycznego zarówno przez władze Królestwa Hiszpanii, jak i w państwach Maghrebu. W szczególności było to utrudnione w okresie rządów dyktatorskich generała Francisco Franco.

\section{Okres frankistowski w polityce Hiszpanii (1939-1975)}

1 kwietnia 1939 r. generał Francisco Franco oficjalnie ogłosił zakończenie wojny domowej. Od tego momentu możemy mówić o niedemokratycznym, autorytarnym państwie hiszpańskim. Na początku podpisano Traktaty o Przyjaźni i Nieagresji z Portugalią oraz z Niemcami. Następnie 4 września 1939 r. zadeklarowano estricta neutralidad (ścisłą neutralność) (Calduch, 1993: 13). Mimo deklarowanej neutralności Hiszpania wystąpiła z Ligii Narodów (8 maja 1939 r.) i zbliżyła się do państw osi. Było to bezpośrednią konsekwencją wcześniejszej pomocy, jaką Franco otrzymał od Niemiec oraz Włoch podczas wojny domowej. 12 czerwca 1940 r. polityka neutralności została zmieniona na no beligerancia, czyli niewalczącą (Miłkowski, Machcewicz, 2009: 350-351). W polityce zagranicznej wyraźny był izolacjonizm. Wyjątkiem stało się otwarcie w 1942 r. konsulatu Stanów Zjednoczonych w Ceucie i w Tangerze (miasto miało status strefy międzynarodowej w latach 1923-1956, a w okresie od 14 czerwca 1940 r. do 1945 r. znajdowało się pod okupacją hiszpańską). Stanowisko hiszpańskiego przywódcy wojskowego - caudillo uległo zmianie po sukcesach III Rzeszy i okupacji Francji. 23 października 1940 r. Franco spotkał się z Hitlerem (w obecności ministrów spraw zagranicznych: Hiszpanii - Ramona Serrano Sunera i Niemiec - Joachima von Ribbentropa) w Hendaya na granicy hiszpańsko-francuskiej. Rozmowa dotyczyła możliwości włączenia się do wojny po stronie państw osi. Hitler oczekiwał od Hiszpanii cesji jednej z Wysp Kanaryjskich, bazy morskiej w Mogadorze (Essaouira) lub w Agadirze oraz Wyspy Fernando Pol (Isla de Bioko) na Oceanie Atlantyckim. Z kolei Franco chciał przejęcia Gibraltaru, Oranu, francuskiego Maroka, Gwinei oraz regionu Rosellón (fr. Roussillon). Oczekiwał ponadto dostaw sprzętu wojskowego, paliwa oraz żywności. Termin przystąpienia Hiszpanii do wojny miał zostać ustalony przez rząd. W lipcu 1941 r. sformowana została 
Błękitna Dywizja (División Azul) z hiszpańskich ochotników, ubranych w niemieckie mundury. Ostatecznie nie zdecydowano się na przystąpienie do wojny. Określano to posunięcie Franco jako tzw. habil prudencia (roztropność), czyli przewidywanie co do efektu końcowego. Analitycy wskazują, że Franco wiedział, iż jego życzenia nie zostaną spełnione i w rzeczywistości nigdy nie rozważał uczestnictwa w wojnie (Morcillo, 2013: 290).

Po zakończeniu II wojny światowej stopniowo odchodzono od retoryki faszystowsko-totalitarnej na rzecz tzw. demokracji organicznej. Niemniej rządy Franco nie uzyskały międzynarodowego uznania. 12 grudnia 1946 r. Zgromadzenie Ogólne Organizacji Narodów Zjednoczonych (ONZ) uchwaliło rezolucję wzywającą wszystkie kraje do zawieszenia stosunków dyplomatycznych z Hiszpanią do czasu utworzenia reprezentatywnego rządu. Polityka zagraniczna tego okresu cechowała się personalizmem, gdyż wszelkie działania determinowane były przez gen. Franco. Była to także polityka pasywna. $\mathrm{Na}$ arenie międzynarodowej odnotowano znikome inicjatywy dyplomatyczne (Calduch, 1993: 4-6). Odpowiednie dla tego okresu określenie to ausencia de política exterior, czyli nieobecność na arenie międzynarodowej. W służbach dyplomatycznych brakowało profesjonalizmu. Ministerstwo Spraw Zagranicznych jedynie wykonywało polecenia gen. Franco. Dyplomacja okresu powojennego nie miała żadnego konkretnego projektu. Niemniej opowiadano się po stronie państw arabskich i nie uznano Izraela. Było to zgodne z wizją Hiszpanii jako pomostu między Europą a światem arabskim (Miłkowski, Machcewicz, 2009: 354-355, 385). Za kadencji Alberto Martína Artajo (szef MSZ w latach 1945-1957) w 1946 r. powstała Dyrekcja Afryki i Bliskiego Wschodu w MSZ (Dirección de Africa $y$ Proximo Oriente).

W świetle tzw. teoria mediterráneaísta (teorii śródziemnomorskiej) linia badań zorientowanych na region śródziemnomorski cechowała się pasywnością, w szczególności w okresie aislamiento (izolacji). Wśród polityków hiszpańskich dominowało podejście wpisujące się do tzw. teoría doméstica de política exterior (niem. Innenpolitik; pol. krajowa teoria polityki zagranicznej), czyli kształtowanie polityki zagranicznej w zależności od kształtu polityki wewnętrznej (dominującej ideologii politycznej i ekonomicznej oraz partii sprawującej władzę) (Vargas-Alzate, 2010: 82). Kształt polityki zagranicznej był bezpośrednio skorelowany z sytuacją wewnętrzną. Nie wykorzystano szansy na pełnienie aktywnej roli w regionie. Dyktatura Franco uniemożliwiała koordynację działań w obszarze społeczno-ekonomicznym, politycznym i kulturowym na obu wybrzeżach Morza Śródziemnego. Brakowało połączenia koncepcji dla obszaru afrykańskiego, śródziemnomorskiego i arabskiego. Hiszpania nie została zaproszona do Europejskiej Wspólnoty Węgla i Stali (EWWiS), Euroatomu ani do Europejskiej Wspólnoty Gospodarczej (EWG). Nie objęto jej również 
planem Marshalla. Wynikało to z autorytarnego systemu rządów. Dopiero 14 grudnia 1955 r. została członkiem ONZ, a w 1959 r. Organizacji Europejskiej Współpracy Gospodarczej (OEEC) (Gola, Ryszka, 1999: 297). Wówczas możemy mówić o końcu okresu aislamiento. Sukcesywnie dynamizowano relacje ze Stanami Zjednoczonymi oraz Europą. Od 1962 r. Hiszpania miała swojego ambasadora przy Wspólnotach Europejskich. W latach 50. XX w. przedstawiciele władz Hiszpanii opracowali dwie inicjatywy integracyjne dotyczące pośrednio bądź bezpośrednio relacji z państwami Maghrebu. Autorem pierwszej był sam generał Franco, który już w 1952 r. zaproponował zawarcie paktu zachodniośródziemnomorskiego z udziałem Hiszpanii, Portugalii, Francji, Włoch i Wielkiej Brytanii. Ponownie z tą koncepcją wystąpił Minister Spraw Zagranicznych Alberto Martín Artajo w 1956 r. Jego propozycja dotyczyła zwołania konferencji państw nadbrzeżnych Morza Śródziemnego z udziałem państw Maghrebu: Maroka i Tunezji. Współpraca miała obejmować nie tylko sprawy polityczne, ale także gospodarcze. Państwa Maghrebu popierały taką wizję współpracy, gdyż chciały uniezależnić się od Francji. Wyraźnym zwolennikiem takiej formuły był król Maroka Mohamed V (panujący w latach 1957-1961). Przeciwko opowiedziała się natomiast Komunistyczna Partia Tunezji, która obawiała się uzależnienia od NATO (Parzymies, 1980: 83-85). Z nowymi inicjatywami dyplomatycznymi wystąpił w 1956 r. minister spraw zagranicznych Fernando María Castiella y Maíz (szef MSZ w latach 1957-1969). Przede wszystkim jego celem było odejście od izolacjonizmu, a także kreowanie nowego wizerunku na arenie międzynarodowej. Hiszpania miała być katolicka i konserwatywna, ale nie faszystowska. Castiella chciał zbliżenia z Europą Zachodnią oraz ustabilizowania relacji z Marokiem. Głębokie reformy były utrudnione przez dyktaturę Franco i związane z nią: cenzurę, nietolerancję religijną, wszechobecną ingerencję Ministerstwa Informacji (Pardo Sanz, Castiella, 2005: 17-18). Niemniej wraz ze zmianą rządu w 1957 r. wprowadzono nowy program reform ekonomicznych, celem zastąpienia autarkii. W poszukiwaniu normalizacji relacji zewnętrznych zaczęto stosować terminologię charakterystyczną dla ustroju demokratycznego. Działania Castielli poprawiły wizerunek Hiszpanii na arenie międzynarodowej za sprawą m.in. pomocy udzielonej państwom arabskim pogrążonym w kryzysie. Istotne były pierwsze przejawy akceptacji dla dekolonizacji (Torrejón, 2005). Kontynuacja obranej polityki zagranicznej widoczna była w pracy jego następców: Gregorio Lópeza Bravo (1969-1973), Laureano Lópeza Rodó (VI-XII 1973) i Pedro Cortiny Mauri (1974-1975). 


\section{Stosunki bilateralne Hiszpanii z państwami Maghrebu}

Relacje z państwami arabskimi opierały się na kwestiach kulturowych. Od lat 50. XX w. Hiszpania zawierała układy z państwami regionu Bliskiego Wschodu i Afryki Północnej (Middle East and North Africa - MENA). W 1958 r. w Fezie odbył się I Kongres Arabski pod auspicjami Organizacji Narodów Zjednoczonych do spraw Oświaty, Nauki i Kultury (UNESCO). Podkreślano na nim m.in. związki między Hiszpanią a Marokiem (kulturowe, geograficzne i historyczne). Określono ją mianem mediatora między Europą a arabską Afryką. Potwierdzeniem otwarcia na świat i wyrazem zerwania z autarkią był Plan Stabilizacji Gospodarczej z 1959 r. Powoli odchodzono od postrzegania Hiszpanii jako państwa frankistowskiego, przeciwnego państwom demoliberalnym (Górski, 1997: 73). W listopadzie 1966 r. Kortezy Generalne uchwaliły ustawę organiczną (Ley orgánica de Estado), na podstawie której 1/5 członków była wybierana w wyborach bezpośrednich przez mężczyzn (Miłkowski, Machcewicz, 2009: 383).

W opozycji do Hiszpanii swoją wizję stosunków z Maghrebem realizowała Francja. Premier Felix Gaillard przedstawił w 1958 r. koncepcję współpracy wojskowej i gospodarczej z krajami tzw. wąskiego Maghrebu, z możliwością rozszerzenia o Hiszpanię, Włochy, Libię, Wielką Brytanię oraz Stany Zjednoczone. Zostało to negatywnie odebrane przez rządzące partie polityczne Tunezji (Neo Dustur) i Maroka (Istiqlal), a także Front Wyzwolenia Narodowego w Algierii. Przede wszystkim zwracano uwage na wojnę domową w Algierii. Odczytano francuską propozycję jako próbę odwrócenia uwagi od sytuacji w tym kraju. Wyrazem jednolitego stanowiska wśród państw Maghrebu była konferencja w Tangerze w kwietniu 1958 r. Jej głównym celem była walka $\mathrm{z}$ wszelkimi pozostałościami kolonializmu. Był to swoisty front przedstawicieli Neo Dustur, Istiqlal oraz Frontu Wyzwolenia Narodowego (Parzymies, 1980: 86-88, 93). Istotny wpływ na politykę zagraniczną Hiszpanii miał proces dekolonizacji i odzyskania niepodległości przez państwa Maghrebu. Polityka zagraniczna oparta była na przyjaźni i współpracy ekonomicznej z państwami arabskimi. Kluczowe stały się ponownie relacje z Marokiem, które odzyskało niepodległość 2 marca 1956 r. Hiszpania popierała marokański ruch narodowy $\mathrm{w}$ walce $\mathrm{z}$ francuskim panowaniem, aczkolwiek uznała niepodległość tego państwa dopiero 7 kwietnia 1956 r., podczas oficjalnej wizyty króla Mohameda V w Madrycie (miesiąc po Francji). Pozostały problemy hiszpańskich posiadłości. Region Tarfaya został zwrócony Maroku w 1958 r. na podstawie Traktatu z Centra z 1 kwietnia. Hiszpania zgodziła się także na zwrot Rif oraz w przyszłości Ifni. Uzależnione to było od pozostania przy Hiszpanii miast Ceuta i Melilla oraz Islas Chafarinas. Nieuregulowany był status Sahary Zachodniej. 
Hiszpanii sprzyjały podziały między krajami Maghrebu i rywalizacja algiersko-marokańska (Larramendi, 2014: 43). W 1958 r. król Mohamed V ponownie skierował wobec Hiszpanii żądania zwrotu Ceuty, Melilli, wysp: Peñón de Velez de la Gomera, Peñón de Alhucemas, Islas Chafarinas i Isla Perejil. Maroko argumentowało, że Ceuta i Melilla są dla nich tym, czym dla Hiszpanii jest Gibraltar (El Mostafa, 2003: 20-21). 30 sierpnia 1961 r. wojska hiszpańskie zostały ostatecznie ewakuowane z Maroka. Regulowano także pozostałe kwestie gospodarcze. 13 maja 1971 r. zawarto Układ o Współpracy Ekonomicznej (Acuerdo de Cooperación Económica entre el Estado Español y el Reino de Marruecos). Już w preambule stwierdzono konieczność rozwijania relacji dwustronnych opartych na wzajemnej przyjaźni i regionalnej solidarności. Kluczowe były zintensyfikowanie oraz pogłębienie współpracy we wszystkich sektorach oraz rozwijanie wymiany handlowej. Z dniem 30 czerwca 1971 r. wygasł Układ o Płatnościach (Acuerdo de Pagos z 21 lipca 1962 r.). Nowy System Płatności w swobodnie wymienialnej walucie miał obowiązywać od 1 lipca $1971 \mathrm{r}$. W treści dokumentu nawiązano do Układu o Wycofaniu Pesety (Acuerdo Hispano-Marroquí de Retirada Peseta z 7 lipca 1957 r.) i Protokołu dodatkowego z 7 lipca 1970 r. Pierwszym krokiem ku skodyfikowaniu kwestii rybołówstwa był Acuerdo de Pesca z 1969 r. Podkreślono w nim historyczne prawo Hiszpanii do eksploatacji wód pod jurysdykcją Maroka, a także zapisano klauzulę najwyższego uprzywilejowania. Na podstawie tego układu wprowadzono trzy strefy połowów: 0-3 mili, 3-6 mili oraz 6-12 mili. Poszczególnym odległościom przyporządkowano zakres czynności możliwych do wykonania oraz określony tonaż.

Libia najwcześniej spośród państw Maghrebu odzyskała niepodległość, bo w grudniu 1951 r. Na czele państwa stanął król Idriss I, który odwiedził Hiszpanię już w 1953 r. Pierwsze umowy z Hiszpanią, w zakresie kultury oraz umowy handlowe, zostały zawarte w 1959 r. (m.in. Convenio cultural z 5 maja 1959 r.). 14 stycznia $1961 \mathrm{r}$. Hiszpania nawiązała z monarchią relacje dyplomatyczne. Polityka względem nowego państwa libijskiego w czasach Franco była zdominowana przez współpracę kulturalną. Nawiązano również kooperację w dziedzinie medycyny, co zapoczątkowało wymianę kadry medycznej. Stopniowo rozwijał się program stypendialny umożliwiający wyjazd naukowcom oraz studentom. Relacje bilateralne zyskały na znaczeniu wraz z odkryciem w Libii złóż ropy naftowej w 1959 r. 14 stycznia 1961 r. podpisano pierwszy kontrakt między kompanią libijską a katalońską. Usankcjonowano także współpracę wojskową w 1965 r. Przewrót z 1 września 1969 r. nie był przeszkodą dla utrzymania dobrych relacji. Muammar al-Kaddafi od zamachu stanu jako dyktator kontrolował wszystkie aspekty polityki. Niemniej nowy rząd został uznany przez Hiszpanię już w pięć dni po przejęciu władzy. Libia była jednym z głównych dostawców energii do Hiszpanii. Podpisywano kolejne układy o współpracy ekonomicznej 
i handlowej oraz naukowej i technicznej (Convenio de Cooperación Económica y Comercial oraz Convenio de Cooperación Científica y Técnica z kwietnia 1974 r.).

Kolejny kraj Maghrebu, Tunezja, odzyskał niepodległość kilkanaście dni po Maroku, 20 marca 1956 r. Od 1961 r. były zawierane umowy hiszpańsko-tunezyjskie (współpraca naukowo-techniczna, handlowa, w dziedzinie transportu lotniczego i kinematografii). Opowiadano się za regionalną współpracą na zasadzie pomocy rozwojowej i zaangażowania w problematykę bezpieczeństwa. Taką wizję kooperacji przedstawił prezydent Habib Bourgiba (urzędujący w latach 1957-1987) już w kwietniu 1965 r. (Parzymies, 1980: 221).

Mauretania ze względu na odległość geograficzną oraz niski poziom rozwoju gospodarczego była najmniej atrakcyjnym partnerem dla Hiszpanii spośród wszystkich krajów Maghrebu. Niepodległość odzyskała 28 listopada 1960 r. Od początku poszukiwała sojuszników (Larramendi, Planet, 2006: 344-347), zwłaszcza w kontaktach z Marokiem. Dążyła do powszechnego uznania jej na arenie międzynarodowej. Pierwszym prezydentem tej republiki islamskiej został Moktar Ould Daddah (20 sierpnia 1961 r.). W tym samym roku Mauretania została członkiem ONZ. Hiszpania niezwłocznie uznała jej niepodległość, czego konsekwencją było utworzenie ambasady w Nouakchott w 1962 r. 14 lutego 1964 r. podpisano Układ o Transporcie Morskim i Lotniczym (Acuerdo sobre transportes marítimos y aereos). W marcu 1966 r. hiszpański minister spraw zagranicznych Fernando María Castiella odwiedził Mauretanię. Zobowiązano się wówczas do konsultacji z Mauretanią wszelkich kwestii związanych z terytorium Sahary Zachodniej. Z kolei hiszpańscy rybacy uzyskali gwarancję dostępu do połowów na wodach terytorialnych Mauretanii (na podstawie Convenio de Cooperación en materia de pesca marítima e industralización de productos de la pesca). Niewątpliwie jedyne znaczenie tego kraju dla Hiszpanii wiązało się z zaangażowaniem w kwestię saharyjską. Mauretania była stroną konfliktu o Saharę Zachodnią, gdzie o wpływy rywalizowała z Algierią, Marokiem oraz Hiszpanią. W 1958 r. zmieniono status Sahary Zachodniej z kolonii na hiszpańską prowincję zamorską z prawem do wystawienia trzech deputowanych do Kortezów Generalnych. 19 kwietnia 1961 r. formalnie Sahara Zachodnia została zrównana z innymi prowincjami. Nie zyskało to akceptacji ze strony Maroka. Zarówno król Mohamed V, jak i jego następca Hassan II (panował w latach 1961-1999) dążyli do wcielenia terytoriów takich jak: Sidi Ifni, Sahara Zachodnia czy Ceuta i Melilla (Chazbijewicz, 2010: 342). 20 grudnia 1966 r. Zgromadzenie Ogólne ONZ uchwaliło rezolucję, w której potwierdzono prawo ludności Sahary Hiszpańskiej do samostanowienia. Hiszpania jako główny zainteresowany zaakceptowała postanowienia, aczkolwiek opóźniała ich realizację. W grudniu 1972 r. (mimo sprzeciwu Hiszpanii oraz wstrzymaniu się od głosu Maroka) uchwalono kolejną rezolucję, przyznając prawo dla narodu 
saharyjskiego do niepodległości. Na spotkaniu w Agadirze, w lipcu 1973 r., Maroko i Mauretania potwierdziły swoje stanowisko odnośnie do podziału strefy wpływów. Jedynie Algieria chciała pełnej niepodległości Sahary. W odpowiedzi rząd hiszpański skierował list do Sekretarza Generalnego ONZ z prośbą o zwołanie referendum w sprawie niepodległości, ale wyłącznie przy udziale przedstawicieli Hiszpanii. Napotkało to zdecydowany sprzeciw ze strony króla Hassana II, który zapowiedział konieczność wyboru między utrzymaniem hiszpańskiego panowania kolonialnego a przyłączeniem terytorium do Maroka. Marokańczycy postanowili wykorzystać niestabilną sytuację w Hiszpanii i w pokojowy sposób przejąć kontrolę nad tym terytorium. 6 listopada 1975 r. zorganizowano tzw. Zielony Marsz. Pretensje do obszaru zgłosiła również Mauretania. Wbrew rezolucji Zgromadzenia Ogólnego ONZ, wzywającej do całkowitej dekolonizacji, Maroko i Mauretania dokonały podziału strefy wpływów w 1975 r. W konsekwencji 14 listopada 1975 r. w Madrycie zawarto porozumienie hiszpańsko-marokańsko-mauretańskie (Acuerdo Tripartito de Madrid), na mocy którego wojsko hiszpańskie miało opuścić terytorium do 28 lutego $1976 \mathrm{r}$. W zamian Hiszpania mogła liczyć na dostęp do eksploatacji fosforytów i połów ryb na wodach marokańskich. Podkreślono również hiszpańskość Ceuty oraz Melilli. Tunezja, mimo niezaangażowania w konflikt, popierała starania Maroka. Po wycofaniu się Mauretanii w 1979 r. jedynym rywalem dla strony marokańskiej w rejonie Sahary Zachodniej było Polisario, popierane przez Algierię. W tym samym roku udało się dojść do porozumienia w Algierze. Traktat pokojowy pozostawił Saharę Zachodnią pod kontrolą Maroka.

Najbardziej burzliwe były dzieje Algierii, która niepodległość odzyskała dopiero po wojnie domowej, 1 marca 1962 r. Zwycięstwo odniósł Front Wyzwolenia Narodowego. Algieria skupiła się na kwestiach politycznych i chciała wyeliminowania pozostałości kolonializmu. Ambasada Królestwa Hiszpanii rozpoczęła swoją działalność w Algierze 22 listopada 1962 r. Początkowo współpraca z Hiszpanią dotyczyła głównie dziedzin takich jak energetyka, transport i handel. Relacje w obszarze kultury po raz pierwszy zostały zinstytucjonalizowane na podstawie konwencji z 19 czerwca 1968 r. - Convenio de Cooperación Cultural, Científica y Técnica. W 1971 r. rozpoczęło w Algierze działalność Centro Cultural Español, zamienione następnie na Oficina Cultural de la Embajada de España. Potwierdzeniem rozwoju współpracy w dziedzinie kultury była druga Konwencja z 1974 r. Podczas Konferencji Szefów Państw i Rządów Organizacji Jedności Afrykańskiej w Algierze w 1968 r. Algieria, Maroko i Mauretania zadecydowały o utworzeniu wspólnego frontu przeciwko Hiszpanii. W styczniu 1969 r. w Ifrane podpisano algiersko-marokański Traktat o braterstwie, stosunkach dobrosąsiedzkich i współpracy, a także Traktat o wzajemnym poszanowaniu suwerenności narodowej i integracji terytorialnej. Granice zostały uregulowane 
ostatecznie na spotkaniu w Rabacie 15 czerwca 1972 r. (Parzymies, 1980: 156, 164166, 169-172, 182-183). Od 1962 r. hiszpańskie Alicante było skomunikowane drogą morską i lotniczą z Algierią. Nastąpił stopniowy rozwój turystyki. Aż do maja $1991 \mathrm{r}$. Algierczycy mogli podróżować do Hiszpanii bez obowiązku wizowego.

Mimo zainteresowania obszarem Maghrebu dla Hiszpanii priorytetem była integracja z Europą Zachodnią. Pierwszym impulsem do zmian był wniosek ministra Castielli o rozpoczęcie negocjacji ze Wspólnotami Europejskimi (9 lutego 1962 r.). Wspominał on o stowarzyszeniu, które w efekcie miało doprowadzić w przyszłości do pełnej integracji. Wniosek pozostał bez odpowiedzi ze strony Brukseli, a Hiszpania wciąż była izolowana na arenie międzynarodowej. Drugi wniosek złożono 14 lutego 1964 r. Ostatecznie otrzymano poparcie Rady Ministrów EWG. Stopniowo stosunki z Wspólnotą Europejską (WE) ulegały intensyfikacji. W 1970 r. w Luksemburgu zawarto Umowę Preferencyjną w Sprawie Handlu (Miłkowski, Machcewicz, 2009: 371-372).

\section{Okres demokratyzacji (1975-1986)}

Hiszpańska pokojowa transición ograniczona była do sfery politycznej. Po śmierci gen. Franco (20 listopada 1970 r.) widoczne było dążenie do demokratyzacji, decentralizacji i powrotu do aktywnej polityki zagranicznej. Początkowo istniały trzy opcje rozwoju polityki zagranicznej: kontynuacja (continuismo), stopniowe reformy (reformismo) i całkowity przełom (ruptura). Teoretycznie opowiedziano się za trzecią wizją. Jednak nie było żadnych przesłanek świadczących o możliwości wprowadzenia tego wariantu w życie, m.in. dlatego, że na stanowisku pozostał premier frankistowski. W pierwszych latach demokratycznych rządów Hiszpania poszukiwała politycznej i dyplomatycznej równowagi względem Maghrebu. Rozwijała relacje bilateralne oparte na własnych interesach, bez zaangażowania w bipolarny podział świata. Za czasów gen. Franco relacje z Maghrebem kształtowały się pomiędzy dwoma skrajnymi biegunami - pokojową kooperacją a otwartym konfliktem. Brakowało pełnego zaufania (Calduch, 1993).

Na podstawie tzw. Acuerdo Tripartito (porozumienia trójstronnego) z Madrytu, z 14 listopada 1975 r., nastąpiła dekolonizacja Sahary Zachodniej. W konsekwencji utworzono administrację z udziałem Maroka oraz Mauretanii. Hiszpańska obecność wg porozumienia miała się zakończyć 28 lutego 1976 r. Ostatecznie 2/3 terytorium przekazano Maroku, a 1/3 Mauretanii. Obydwa państwa porozumiały się odnośnie do granicy 14 kwietnia 1976 r. (Chazbijewicz, 2010). Strona hiszpańska zobowiązała się do pomocy dla ludności cywilnej oraz dla funkcjonariuszy wojskowych i pozostałych pracowników, którzy musieli opuścić terytorium Sahary Zachodniej. Przygotowano 1 mld peset na pokrycie kosztów podróży i diet. 
Do prawdziwego przełomu w polityce zagranicznej Hiszpanii, a także w relacjach z państwami Maghrebu, doszło dopiero po przejęciu władzy przez Hiszpańską Socjalistyczną Partię Robotniczą (PSOE) w listopadzie 1982 r. W tym okresie relacje bilateralne między Hiszpanią a Mauretanią skupiały się na obszarze rybołówstwa. W tym samym roku porozumiano się w kwestii nowej wizji współpracy w zakresie rybołówstwa, a ściślej budowy stoczni, modernizacji łodzi rybackich oraz sprzętu wędkarskiego, komercjalizacji produktów rybołówstwa, promocji przemysłu przetwórczego produktów rybnych. Zapowiedziano współpracę naukową i techniczną, wymianę badaczy oraz informacji w dziedzinie oceanografii czy biologii morskiej. Hiszpania zobowiązała się do wprowadzenia ułatwień w dostępie na rynek produktów mauretańskich. Z kolei Mauretania miała zapewnić określonej liczbie statków hiszpańskich dostęp do połowów na swoich wodach. Układ miał obowiązywać przez trzy lata, z opcją odnowienia na kolejny rok pod warunkiem niewypowiedzenia go przez żadną ze stron.

Wyrazem traktowania Maghrebu jako całości była sformułowana przez Hiszpanię w 1983 r. tzw. política global. Celem było odejście od uprzywilejowanych relacji z jednym państwem na rzecz równowagi w stosunkach ze wszystkimi krajami Maghrebu. Należało uniezależnić się od jednego partnera (w tym kontekście od Maroka), aby wypracować sieć zależności w obszarze politycznym, gospodarczym, społeczno-kulturalnym czy w dziedzinie bezpieczeństwa. Instrumentami, które miały temu służyć, były: dialog polityczny na różnych szczeblach, wspólne działania w zakresie bezpieczeństwa, ochrony kultury i społeczeństwa. Od akcesji do NATO 30 maja 1982 r., a później do Wspólnot Europejskich, redefinicja polityki śródziemnomorskiej była koniecznością (zarówno jej rozszerzenie, jak i multilateralizacja). Większy nacisk położono na rozwiązywanie konfliktów i usytuowanie Hiszpanii jako potęgi regionalnej. Polityka śródziemnomorska miała być kompatybilna z iberoamerykańską oraz atlantycką. Hiszpanii w sposób szczególny zależało na stabilności i bezpieczeństwie państw Maghrebu, gdyż było to niezbędne dla bezpieczeństwa całego regionu zachodniośródziemnomorskiego. W konsekwencji jednymi z głównych instrumentów polityki były negocjacje dyplomatyczne, a także wzrost wymiany handlowej i wystarczająca zdolność wojskowa. Polityka oparta była na środkach budowy zaufania, a nie zastraszania czy przymusu. Stabilizacja regionu miała się odbywać poprzez rozwój jego państw. Było to nie zawsze łatwe dla rządów, zwłaszcza hiszpańskiego i marokańskiego (chociażby ze względu na kwestię Ceuty i Melilli). Pierwsze symptomy wspomnianych zmian pojawiły się już za czasów rządów Adolfo Suareza w 1979 r.

Kolejnym przejawem uregulowania spraw hiszpańsko-marokańskich związanych z rybołówstwem był Acuerdo de pesca z 11 lutego 1977 r. Strona marokańska nie ratyfikowała tego układu ze względu na zapisy dotyczące ograniczenia połowów 
oraz postępującą marokanizację statków, które miałyby stanowić przyszłe wspólne przedsięwzięcia. Układ ratyfikowano dopiero podczas wizyty króla Juana Carlosa w Maroku w 1979 r. Już w 1973 r. Marokańczycy rozszerzyli swoje wody terytorialne do 70 mil morskich, a w 1982 r. utworzono Wyłączną Strefę Ekonomiczną (Zona Económica Exclusiva). W preambule Protokołu do Układu o okresie przejściowym w materii rybołówstwa podkreślano konieczność intensyfikacji „serdecznych relacji i ich rozwoju na rzecz dobra wspólnego". Po wzajemnych wizytach króla Hiszpanii i Maroka uznano, że konieczny jest rozwój współpracy w zakresie rybołówstwa tak, aby była ona satysfakcjonująca dla obydwu stron. Podstawą było wzajemne zaufanie oraz respektowanie interesów. Flota hiszpańska wymieniona w protokole mogła wykonywać określone czynności na wodach pod jurysdykcją Maroka pod warunkiem respektowania Aneksu I Układu z 17 lutego 1977 r. i w przypadku wypłacenia odpowiednich kwot (w zależności od tonażu oraz położenia na północ bądź na południe od Cabo Noun-Cap Draa). W ciągu piętnastu dni od podpisania protokołu strona hiszpańska miała dostarczyć kompletną listę statków rybackich. Wspomniany w protokole okres przejściowy ustalono na trzy miesiące (od 1 lipca 1979 r.) z opcją przedłużenia o kolejne trzy (docelowo do 31 grudnia 1979 r.). Z kolei Układ o współpracy w rybołówstwie z 1983 r. realizował nową wizję współpracy. Wprowadził uprzywilejowane traktowanie - licencję dla wskazanych statków hiszpańskich na okres dwóch lat. W Aneksie I określono akceptowalny tonaż, natomiast w Aneksie II warunki korzystania z preferencyjnego traktowania, dokładną odległość od wybrzeża atlantyckiego bądź Morza Śródziemnego. Wprowadzono trzy strefy połowów: dwie były analogiczne jak w układzie z 1979 r. i wyznaczał je Cabo Noun. Trzecia obejmowała obszar pomiędzy Larache i Tangerem (6 mil zarezerwowanych dla rybaków marokańskich). Strona hiszpańska zobowiązała się do regularnego przesyłania statystyki dotyczącej połowów na wodach marokańskich w ciągu $60 \mathrm{dni}$ od zejścia na ląd. Ponadto zadeklarowano ufundowanie trzydziestu stypendiów na pobyt w Hiszpanii w celu zdobycia kwalifikacji przez Marokańczyków i rozwoju ich rybołówstwa. Oprócz tego umożliwiono czterdziestu osobom minimum półroczne szkoleniowe pobyty na statkach hiszpańskich. Również podczas połowów na wodach marokańskich na statkach pod banderą hiszpańską przebywało po dwóch marokańskich marynarzy. Komisja mieszana przygotowywała rekomendacje oraz powoływała grupy robocze. Spotkania odbywały się naprzemiennie w Madrycie i Rabacie, minimum raz na rok, na wniosek każdej ze stron. Układ miał obowiązywać przez cztery lata. W przypadku akcesji Hiszpanii w tym okresie do Wspólnot Europejskich zapowiedziano jego rewizję oraz wprowadzenie odpowiednich modyfikacji.

13 sierpnia 1984 r. w Oujda Hassan II i Kaddafi podpisali Traktat Ustanawiający Unię Arabsko-Afrykańską. Hiszpania obawiała się możliwych konsekwencji paktu 
libijsko-marokańskiego, zwłaszcza w kontekście potencjalnego zagrożenia dla miast Ceuta i Melilla. Niepokój wzbudzała przede wszystkim deklaracja militarnego wsparcia ze strony Libii. Kaddafi uważał, że Ceuta i Melilla to miasta arabskie i zapowiadał swoje wsparcie dla Maroka. Niemniej barierą dla ściślejszej kooperacji libijsko-marokańskiej był konflikt na linii Algieria-Maroko. Traktat przetrwał tylko dwa lata. 26 sierpnia 1986 r. Hassan II wypowiedział go, kiedy libijski przywódca skrytykował Maroko po oficjalnym spotkaniu w Ifrane z premierem Izraela Simonem Peresem. W relacjach między Hiszpanią i Marokiem pojawiły się również problemy związane z ustanowieniem Ley de Extranjería w 1985 r. Ustawa o cudzoziemcach przyznawała ułatwienia w nabywaniu obywatelstwa przez cudzoziemców o tożsamości i kulturowych powiązaniach z Hiszpanią. Nie uznano jednak praw mieszkańców Ceuty i Melilli pochodzenia arabskiego i berberyjskiego. Dopiero po protestach przyznano im prawo nabywania obywatelstwa na zasadzie prawa ziemi w przeciwieństwie do obowiązującego na półwyspie iberyjskim prawa krwi (Larramendi, 2014).

Libia inwestowała przede wszystkim w sektor bankowy. Kiedy w 1975 r. powstał Banco Árabe España (Aresbank), 30\% kapitału miał Libyan Arab Foreign Bank. W 1976 r. Kaddafi obiecał pomoc Ruchowi Samostanowienia i Niepodległości Wysp Kanaryjskich (El Movimiento por la Autodeterminación y la Independencia de Canarias - MPAIAC), który był wspierany przez rząd algierski. W konsekwencji król Juan Carlos wysłał swojego ojca z oficjalną wizytą do Libii w 1978 r., aby przeciwdziałać wzmacnianiu pozycji wspomnianej organizacji. 5 września 1979 r. ambasada libijska w Madrycie została napadnięta przez bandytów libijskich. Podobne przypadki odnotowano w innych krajach. Generowało to napięcie w relacjach dyplomatycznych hiszpańsko-libijskich. Z kolei w latach 1984-1985 odnotowano kryzys ekonomiczny. Państwo hiszpańskie zamroziło zakup libijskiej ropy naftowej. W odpowiedzi Libia anulowała kontrakty na zakup hiszpańskiego obuwia. Konflikt był przedmiotem rozmów podczas wizyty Kaddafiego na Majorce w grudniu 1984 r. Ostatecznie 21 marca 1985 r. podpisano układ, na mocy którego zrewidowano kwotę długu libijskiego i zezwolono na zapłatę jego części ropą naftową. Niezależnie od problemów ekonomicznych rozwijała się współpraca naukowa.

Współpraca z Algierią była istotna zwłaszcza z powodów ekonomicznych. W lipcu 1985 r. podpisano Układ o Współpracy Ekonomicznej - Acuerdo Marco de Cooperación Económica entre el Gobierno de España y el Gobierno de la República Argelina Democrática y Popular, w którym zapowiedziano harmonijny oraz dynamiczny rozwój polityki ekonomicznej państw we wszystkich obszarach związanych z gospodarką. Układ został zawarty na okres pięciu lat, z możliwością sześciomiesięcznego wypowiedzenia przez każdą ze stron. Szczególnie zaangażowane we współpracę miały być: algierskie Centro Nacional de Comercio Exterior (CNCE) i hiszpański Instituto 
Nacional de Fomento de la Exportación (INFE). Przedmiotem współpracy bilateralnej były także kwestie związane z energią. Już 14 sierpnia 1975 r. podpisano kontrakt między hiszpańską firmą La Empresa Nacional de Gas (ENAGAS) a algierską SONATRACH. Na przełomie lat 70. i 80. pojawił się projekt utworzenia morskiego gazociągu między Algierią (Orán) i Hiszpanią (Almería) z przedłużeniem na terytorium Francji, tzw. Project Segamo.

Relacje bilateralne z Tunezją w latach 70. i 80. wyznaczone były przez Układ o Współpracy w Transporcie Lotniczym oraz o Współpracy w Turystyce. W pierwszym z nich zapowiedziano rozwój transportu lotniczego na podstawie przepisów prawa międzynarodowego sformułowanych w Konwencji o Lotnictwie Cywilnym z 7 grudnia 1944 r. W aneksie określono trasę tunezyjską z trzema miejscami docelowymi w Hiszpanii oraz hiszpańską z analogiczną liczbą w Tunezji. Strony zobowiązały się do informowania nawzajem $\mathrm{z}$ trzydziestodniowym wyprzedzeniem o godzinach i częstotliwości lotów autoryzowanych kompanii lotniczych. Ponadto wprowadzono możliwość zakładania szkół lotniczych przez wskazane firmy na terytorium stron układu. W drugim układzie już w preambule podkreślono znaczenie ekonomiczne branży turystycznej w rozwoju gospodarczym obydwu państw. Zapowiedziano ułatwienia w zakresie procedur wjazdowych, a także współpracę w zakresie promocji, infrastruktury, inwestycji, wymiany informacji oraz doświadczeń. Przewidziano stypendia umożliwiające wymianę ekspertów w dziedzinie turystyki. Powołano Komisję Mieszaną ds. Współpracy w Turystyce, której członkowie mieli się spotykać naprzemiennie w Hiszpanii i Tunezji. Jej celem była analiza oraz ustalenie programów rocznej współpracy. Układ miał obowiązywać przez okres pięciu lat z możliwością przedłużenia o kolejny rok.

Tabela 1. Wybrane inicjatywy w polityce zagranicznej a dominująca partia polityczna

\begin{tabular}{|l|l|c|l|}
\hline $\begin{array}{c}\text { Minister Spraw } \\
\text { Zagranicznych } \\
\text { (nazwisko) }\end{array}$ & \multicolumn{1}{|c|}{ Partia polityczna } & $\begin{array}{c}\text { Okres } \\
\text { sprawowania } \\
\text { funkcji }\end{array}$ & \multicolumn{1}{|c|}{ Ważne inicjatywy } \\
\hline Serrano Suner & Movimiento Nacional & $1940-1942$ & Polityka no beligerancia \\
\hline Martin Artajo & Movimiento Nacional & $1945-1957$ & $\begin{array}{l}\text { Niepodległość państw } \\
\text { Maghrebu }\end{array}$ \\
\hline Castiella y Maiz & Movimiento Nacional & $1957-1969$ & $\begin{array}{l}\text { Wniosek o rozpoczęcie } \\
\text { negocjacji z EWG }\end{array}$ \\
\hline López Bravo & Movimiento Nacional & $1969-1973$ & Acuerdo de Pesca I \\
\hline Cortina Mauri & Movimiento Nacional & $1974-1975$ & Zielony Marsz \\
\hline Oreja Aguirre & $\begin{array}{l}\text { Unia Demokratycznego Centrum (UCD; koalicja pod } \\
\text { przewodnictwem Partii Ludowej (PP)) }\end{array}$ & $1976-1980$ & Acuerdo de Pesca II i III \\
\hline Moran López & Hiszpańska Socjalistyczna Partia Robotnicza (PSOE) & $1982-1985$ & Politica global \\
\hline
\end{tabular}

Źródło: opracowanie własne. 


\section{$* * *$}

W okresie przedakcesyjnym w Hiszpanii wyodrębniły się w polityce zagranicznej dwa główne kierunki: maghrebiński oraz europejski. Poprzez akcesję do WE Hiszpania stała się stroną porozumień zawartych z państwami Maghrebu. Na podkreślenie zasługuje fakt, że Wspólna Polityka Rolna i Wspólna Polityka Handlowa nie objęły Ceuty i Melilli oraz przejściowo Wysp Kanaryjskich (do 1991 r.). Poświęcono temu obszarowi protokół nr 2, w którym stwierdzono, że nie obowiązują zapisy art. 9 i 10 Traktatu Ustanawiającego Europejską Wspólnotę Gospodarczą dla produktów pochodzących z Wysp Kanaryjskich, Ceuty i Melilli oraz importowanych z państw trzecich i znajdujących się na wyżej wymienionym obszarze. Z perspektywy XXI wieku można wyprowadzić wnioski, że zarówno dla premierów z PP, jak i PSOE priorytetem była kwestia europejska. Niemniej widoczna jest aktywność w obszarze relacji bilateralnych, głównie z Marokiem, w którego przypadku dominują umowy o profilu ekonomicznym. W świetle rozwoju tzw. teoria mediterráneaísta linia badań zorientowanych na region śródziemnomorski cechowała się początkowo pasywnością, w szczególności w okresie aislamiento. Nie wykorzystano szansy na odgrywanie aktywnej roli w regionie w czasie dekolonizacji państw Maghrebu. Dopiero za sprawą trzech wydarzeń Hiszpanię można uznać za równoprawny podmiot stosunków międzynarodowych, który odgrywa ważną rolę i wpływa na politykę europejską. Są to chronologicznie: transformacja ustrojowa - uchwalenie nowej konstytucji i restytucja monarchii; przejęcie władzy przez PSOE; akcesja do WE.

Takie uporządkowanie zebranego materiału miało na celu upowszechnienie wiedzy na temat mniej popularnej problematyki polityki zagranicznej Hiszpanii w omawianej perspektywie czasu. Wskazane przykłady posłużyły do potwierdzenia tezy o dominacji podejścia tzw. teoría doméstica de política exterior, gdyż w zależności od sytuacji wewnętrznej kształtowane były priorytety polityki zagranicznej Hiszpanii.

\section{Bibliografia}

Calduch, R.C. (1993). Dinamica de la Sociedad Internacional. Madryt: Ceures.

Chazbijewicz, S. (2010). Polityczny konflikt o terytorium Sahary Zachodniej. Forum Politologiczne, 10: $337-351$.

El Mostafa, N. (2003). Analisis de los acuerdos hispano-marroquies y sus efectos en las relaciones economicos y comerciales entre Marruecos y Espana (1956-2003). Madryt: UAM.

Gola, B., Ryszka, F. (1999). Hiszpania. Warszawa: Trio.

Górski, E. (1997). O demokracji w Hiszpanii (1975-1995). Warszawa: IFiS PAN. 
Larramendi, M.H. (2014). Las relaciones exteriors de Espana con el mundo arabe y musulman durante el siglo XX. Awraq, 9: 39-54.

Larramendi, M.H., Planet, A.I. (2006). Las relaciones hispano-mauritanas (1960-2006). Anales de Historia Contemporanea, 23: 343-364.

Małkowski, T., Machcewicz, P. (2009). Historia Hiszpanii. Wrocław: Zakład Narodowy im. Ossolińskich.

Morcillo, H. (2013). Violación de la neutralidad de España durante Segunda Guerra Mundial. Estudios Humanisticos. Historia, 12: 289-307.

Pardo Sanz, R., Castiella, F.M. (2005). Una larga travesia hacia el liberalism. W: Historia y cultura: 393-427. J. Aviles (ed.). Madryt: UNED.

Parzymies, S. (1980). Polityka śródziemnomorska państw Maghrebu. Warszawa: Wydawnictwo MON.

Pereira Castanares, J.C. (2004). Franquismo, política exterior y memoria historica. Madryt: Marcial Pons.

Szatur-Jaworska, B. (red.) (2018). Polityki publiczne. Wybrane zagadnienia teoretyczne i metodologiczne. Warszawa: Wyd. Uniwersytetu Warszawskiego.

Torrejón Rodriguez, J.D. (2005). Las relaciones entre Espana y Marruecos segun sus Tratados Internacionales. Kadyks: Serie de Estudios Internacionales.

Vargas-Alzate, L.F. (2010). Debate entre política exterior y relaciones internacionales. Una reactivación del orden teórico. REVISTA Universidad EAFIT, 46(157): 75-90.

Unless stated otherwise, all the materials are available under the Creative

Commons Attribution 4.0 International license. Some rights reserved

to SGH Warsaw School of Economics.

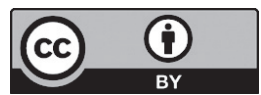

